\title{
Editorial - Global China Beyond the Belt and Road Initiative
}

Ivan Franceschini

\section{(2) OpenEdition \\ 1 Journals}

Electronic version

URL: https://journals.openedition.org/chinaperspectives/10918

DOI: 10.4000/chinaperspectives.10918

ISSN: 1996-4617

Publisher

Centre d'étude français sur la Chine contemporaine

\section{Printed version}

Date of publication: 1 December 2020

Number of pages: $3-5$

ISSN: 2070-3449

\section{Electronic reference}

Ivan Franceschini, "Editorial - Global China Beyond the Belt and Road Initiative", China Perspectives

[Online], 2020/4 | 2020, Online since 01 December 2020, connection on 10 December 2021. URL:

http://journals.openedition.org/chinaperspectives/10918; DOI: https://doi.org/10.4000/

chinaperspectives. 10918 


\title{
Global China Beyond the Belt and Road Initiative
}

\author{
IVAN FRANCESCHINI
}

$\mathrm{n}$ the past few years, China's increasing assertiveness on the international stage has made headlines all over the world, causing considerable discussion and concern among scholars, practitioners, and policymakers. However, the contentiousness of China's global engagements is nothing new. Already in the 1950s, the Chinese authorities played a fundamental role in the creation of the non-aligned movement and began sending abroad technicians and workers to provide assistance to other developing countries in what would later come to be known as the Global South (Sorace and Zhu, forthcoming). Then, in the 1960s, in the wake of the Sino-Soviet split and at the height of the Cold War, the Chinese leadership committed to waging Third World struggle against the twin imperialisms of the United States and the Soviet Union, a position known as "third-worldism" (Brautigam 2009: 37; Teng 2019; Galway, forthcoming). China's global role continued to be at the centre of heated debates even in later decades as the Cold War wound down, China embarked on its path of economic reform, and the Chinese partystate set aside the anti-colonial project underpinning this rhetoric. The 1990s saw Chinese companies beginning to "go out," but the real turning point for China's international engagement came in the late 1990s and early 2000s, as Beijing officially announced the "China Goes Global" strategy and concurrently joined the World Trade Organisation (Hong and Sun 2006; Ye 2020: 84 and following). If this landmark event fostered liberal hopes for the country's supposed democratic future, it also led to widespread concern over how China's social dumping might affect other economies (Solinger 2009). Then came the Belt and Road Initiative (BRI, yidai yilu一帶一路).

Xi Jinping first announced the BRI during state visits to Kazakhstan and Indonesia in late 2013, but the Initiative gradually took shape over the following months and years. According to the official action plan released in March 2015, the BRI rests on five pillars: policy coordination, facilities connectivity, unimpeded trade, financial integration, and peopleto-people contacts. ' Soon, wild figures began circulating, the most widely cited estimating that the BRI investment would add over one trillion USD of outward funding for foreign infrastructure in the decade starting from 2017 (OECD 2018: 3). Such ambitiousness rattled nerves in Western policy circles. Although many scholars have since highlighted how the BRI is in many respects chaotic and very far from being the masterplan for world dominance envisaged by the Chinese authorities (Jones and Zeng 2019), the Initiative has had the effect of rekindling old Cold War fears about China's global rise and influence. Boosted by propaganda efforts from the Chinese authorities and an often equally robust critical response, the debate has since become polarised. On one extreme are those who see the BRI as a benign plan under the aegis of South-South cooperation that will boost infrastructure in countries that could not otherwise afford it, thus reviving their ailing economies; on the other are those who argue that development aid and foreign investment are ultimately a Trojan horse through which the Chinese authorities aim to extract much needed resources, appropriate strategic assets, and boost their political influence. This, joined with the fact that today Chinese actors are more eager than ever to associate themselves with the BRI for purposes that range from economic gain to political legitimacy, has led to a disproportionate focus on the Initiative as a frame to understand China's global engagements.

Drawing from the conference "Chinese Global Engagement Abroad: Changing Economic, Social, and Political Configurations," held at the Hong Kong University of Science and Technology in July 2019, this special issue advances two main arguments. The first argument is that the current overwhelming focus on the BRI leads us to neglect other significant dimensions of the phenomenon called "Global China." As Ching Kwan Lee has argued in her path-breaking monograph The Specter of Global China (2017: xiv): "Global China is taking myriad forms, ranging from foreign direct investment, labor export, and multilateral financial institutions for building cross-regional infrastructure to the globalization of Chinese civil society organizations, creation of global media networks, and global joint ventures in higher education, to name just a few examples." In other words, Global China is far more than the BRI alone and should be understood not only through the geopolitical and economic frames that dominate the current debate, but also in broader terms that take into account the extreme variety of China's international engagements and without losing sight of how these are connected to domestic dynamics. To quote Lee once again, studying Global China means "reimagining China beyond China, connecting, contextualizing, and comparing 'Chinese' development with that in other parts of the world" (ibid.). This is exactly what the contributors to this issue do, whether they discuss the rise of a host of powerful international construction contractors, how the Chinese official trade union is engaging with the labour movement in Cambodia, the impact of Chinese capital in the gambling industry on host societies in the Philippines and in Zambia, or the way Chinese investors in the scrap industry are remoulding the sector at a global level.

Second and directly related to the first point, this special issue also contends that many of the current analyses that focus on the BRI tend to put too much emphasis on what is observable at the moment, neglecting

1. "Vision and actions on jointly building Belt and Road," Belt and Road Forum for International Cooperation website, 10 April 2017, http://www.beltandroad2019.com/english/n100/2017/0410/ c22-45.html (accessed on 12 November 2020). For a discussion of the policy implications, see Garlick 2019. 
the history and background of what we are witnessing today. Instead, we argue that a solid understanding of China's politics and society in historical perspective is a necessary prerequisite for any analysis of Global China. Several contributions to this issue make this point clear. For instance, Hong Zhang shows that, although the days in which Chinese foreign aid was largely motivated by ideological reasons are ostensibly gone, the political economy of yesterday played a fundamental role in enabling an initiative as ambitious as the BRI and still reverberates in the activities of Chinese international construction contractors. In a similar vein, Tabitha Speelman adopts a diachronic perspective to discuss how China is tackling the reform of its immigration as it becomes a privileged destination for foreigners. Finally, Schulz puts the international scrap business in historical perspective, dissecting the complex interactions between Chinese and global dynamics in this sector since the 1990s. All of this shows that without an adequate understanding of China's history and background, it is easy to make misplaced inferences about the unobservable, such as the intentions and the goals of various actors.

The special issue includes five research articles. In the first paper, Tabitha Speelman addresses an under-explored facet of Global China: China's changing role as a destination for international immigration. She does so through the lens of the establishment in 2018 of the National Immigration Administration, the country's first national-level agency dedicated to immigration affairs. The most recent official data are from 2010, when China's census recorded 593,832 foreigners residing in the country for at least three months. While this was only about $0.05 \%$ of the Chinese population at that time, the figure still represented a significant increase from the early reform era, when around 20,000 foreign nationals lived in China. This has not only posed important challenges at a policy level, but has also fundamentally altered the perception of foreign immigrants among the populace - something that has become even more evident in the wake of the BRI, which includes a range of mobility-boosting plans. In such a context, Speelman sheds new light on the bureaucratic dimension of immigration to China, as well as on the policy debates that surround the growing inflow of foreigners into the country. This provides an important addition to the current literature on immigration to China, which so far has been quite marginal and has largely focused on the circumstances and integration of specific groups of immigrants, such as the Arab communities in Yiwu and the African communities in Guangzhou (see, for instance, Wen 2020, and Castillo 2020).

In the second paper, Hong Zhang proposes an archaeology of the BRI. She does so by excavating the roots in the Maoist era of one of the most important and often overlooked actors in Chinese-financed infrastructure projects abroad, China's international construction and engineering contractors (ICECS). As she points out, this industry is born of aid-delivering entities that initially were administered by China's line ministries and subnational governments and which were then stripped of their governmental status and incorporated into firms in the 1980s and 1990s. In her paper, Zhang also explores the relationship between Chinese ICECs and China's development cooperation practices, highlighting how these actors play a greater role in determining the agenda of the Chinese authorities than generally thought - a dynamic that she encapsulates in the innovative concept of "aid-contracting nexus." This original focus on the role of contractors allows Zhang to advance a novel critique of the "debt trap" narrative that in recent years has dominated discussions of Global China and the BRI. Rather than attempting to cajole foreign governments to give up strategic assets and resources, she argues that the focus on infrastructure in China's international development engagements is more of an external manifestation of its industrial policy to foster globally competitive industrial exporters at home - a "mercantilist" practice rather than "predatory" one.

In the third paper, I focus on a seldom-discussed dimension of the BRI and Clobal China, trade union diplomacy. Over the past decade, the official Chinese trade union - the All-China Federation of Trade Unions (ACFTU) - has repeatedly revised the articles of its constitution that outline its international mission. Already in 2013, an amendment called on the organisation to "promote the formation of a fair, rational, democratic, and harmonious new international order for the labour movement." While this phrasing was subsequently dropped, the ACFTU today is required to "actively join in the establishment of the Belt and Road Initiative," a goal that it pursues mostly through people-to-people exchanges. By taking Cambodia as a case study, I highlight how the ACFTU actively engages with and supports local pro-government unions, boosting their standing in a situation in which independent unions and labour NGOs operate under increasingly severe constraints. I also show that the Chinese union officials in their exchanges promote a corporatist model of trade unionism that puts much emphasis on efficiency and financial sustainability - a model that is very appealing for state-aligned unions with legitimacy and financial concerns.

In the fourth paper, Alvin Camba and Hangwei Li compare gambling dens in the Philippines and in Zambia to foreground the relationship between Chinese gambling capital, labour migration, and workplace exploitation. This study makes at least two important contributions to the literature on Global China. First, in a context in which discussions of overseas Chinese investment generally focus on the most visible manifestations of these flows of money, especially infrastructure, Camba and Li delve into the dynamics that underpin the shadowy private capital that fuels the global gambling industry, a market of hundreds of billions of dollars that often escapes official scrutiny. Second, they add to the debate about labour conditions in Chinese-invested companies abroad by bringing to light the linguistic dimension of exploitation. As Chinesefunded gambling firms in both the Philippines and Zambia cater mostly to a Chinese-speaking audience, they rely on the "linguistic labour" of Chinese workers whom they have to import from abroad. Once in the host country, these workers find themselves in a position of vulnerability that enables the worst abuses.

In the fifth and final paper, Yvan Schulz explores the changing nature of China's international engagements in the scrap business over three decades. In particular, he distinguishes three phases. First, in the 1990s, Chinese businessmen involved in this sector were mostly private, often self-made entrepreneurs who eked out a living by buying scrap in industrialised regions of the world and then bringing them back to China for processing. Second, in the 2000s the industry remained largely in the hands of the same socio-economic actors, but developing countries became a privileged destination and the Chinese authorities took the first steps to regulate scrap inflows into China. Finally, in the 2010s, the central and provincial governments took action to better control and monitor imports of scrap and waste material under the banner of China's "ecological civilisation." This led to the collapse of the rural recycling economy and to the relocation of the Chinese scrap processing industry abroad, often at the hand of large state-owned waste management companies. In tracing this history, Schulz painstakingly links domestic and 
international developments, showing how the Chinese authorities have gradually tightened their grip on the national economy and how this has had reverberations globally.

Although over the past year, Covid-19 has disrupted many of the dynamics described above, Global China is here to stay. This requires the academic community to set aside old Orientalist, exceptionalist, and essentialist conceptions of everything Chinese to engage with China as an entity entangled in a complex web of relations and linkages with the rest of the world (Franceschini and Loubere 2020). It also calls for an increased ability to go beyond simplistic narratives to highlight the interrelations between domestic and international developments within the context of a global system that functions according to capitalist logics. The five contributions in this special issue represent a step in this direction, and more will surely follow.

\section{Acknowledgements}

I My gratitude goes to Eric Florence, with whom we first began discussing the possibility of holding a conference on Global China back in 2018. I am also grateful to Sébastien Colin for his help in the early stages of putting this special issue together, and to the editorial board of China Perspectives for their guidance in this process. This issue draws from the conference "Chinese Global Engagement Abroad: Changing Social, Economic, and Political Configurations," held at the Hong Kong University of Science and Technology in July 2019 , so a debt of gratitude is due not only to all participants and discussants but also to the organisers, in particular Kellee Tsai. Finally, I wish to thank Hong Zhang for her feedback in drafting this editorial.

I Ivan Franceschini is a Postdoctoral Fellow at the Australian Centre on China in the World, The Australian National University, and Co-editor-inChief of the open access quarterly Made in China Journal. China in the World Building \#188, Fellows Lane, The Australian National University Canberra ACT 2601, Australia (ivan.franceschini@anu.edu.au).

\section{References}

BRAUTIGAM, Deborah. 2009. The Dragon's Gift: The Real Story of China in Africa. Oxford: Oxford University Press.

CASTILLO, Roberto. 2020. African Transnational Mobility in China: Africans on the Move. London: Routledge.

FRANCESCHINI, Ivan, and Nicholas LOUBERE. 2020. "What about Whataboutism? Viral Loads and Hyperactive Immune Responses in the China Debate." Made in China Journal 5(2): 18-30.

GALWAY, Matthew. 2021 (forthcoming). "Building Uhuru: Chinese Workers and Labour Diplomacy on the Tan-Zam Railway." In Ivan Franceschini, Christian Sorace, Nicholas Loubere, and Kevin Lin (eds.), Proletarian China: A Century of Chinese Labour. London and New York: Verso Books.

GARLICK, Jeremy. 2019. The Impact of China's Belt and Road Initiative: From Asia to Europe. London and New York: Routledge.

HONG, Eunsuk, and Laixiang SUN. 2006. "Dynamics of Internationalization and Outward Investment: Chinese Corporations' Strategies." The China Quarterly 187: 610-34.

JONES, Lee, and Jinghan ZENG. 2019. "Understanding China's 'Belt and Road Initiative': Beyond Grand Strategy to a 'State Transformation' Analysis." Third World Quarterly 40(8): 1415-39.

LEE, Ching Kwan. 2017. The Specter of Global China: Politics, Labor, and Foreign Investment in Africa. Chicago and London: The University of Chicago Press.
OECD. 2018. "China's Belt and Road Initiative in the Global Trade, Investment, and Finance Landscape." OECD Business and Finance Outlook 2018. https://www.oecd.org/finance/Chinas-Belt-and-RoadInitiative-in-the-global-trade-investment-and-finance-landscape.pdf (accessed on 12 November 2020).

SOLINGER, Dorothy. 2009. States' Gains, Labor's Losses: China, France, and Mexico Choose Global Liaisons 1980-2000. Ithaca and London: Cornell University Press.

SORACE, Christian, and Ruiyi ZHU. 2021 (forthcoming). "The shortlived Eternity of Friendship: Chinese Workers in Socialist Mongolia (1955-64)." In Ivan Franceschini, Christian Sorace, Nicholas Loubere, and Kevin Lin (eds.), Proletarian China: A Century of Chinese Labour. London and New York: Verso Books.

TENG, Wei. 2019. "Third World." In Christian Sorace, Ivan Franceschini, and Nicholas Loubere (eds.), Afterlives of Chinese Communism: Political Concepts from Mao to Xi. London and New York: Verso Books. 281-85.

WEN, Meizhen. 2020. "Arab Traders Pursuing Chinese Dream in East China." PhD dissertation. Canberra: The Australian National University.

YE, Min. 2020. The Belt and Road and Beyond: State-mobilized Globalization in China 1998-2018. Cambridge: Cambridge University Press. 